\title{
PENGARUH KETERAMPILAN MANAJERIAL KEPALA SEKOLAH \\ DAN PELAYANAN TENAGA ADMINISTRASI TERHADAP \\ EFEKTIVITAS KERJA GURU SMA NEGERI \\ DI KABUPATEN INDRAMAYU
}

\section{Supiyanto \\ SMA Negeri 1 Juntinyuat Indramayu. Email: supivanto04091964@gmail.com}

Received January 3, 2020, reviewed January 20, 2020, published Apr 30, 2020

Citation: Supiyanto. (2020). Pengaruh Keterampilan Manajerial Kepala Sekolah Dan Pelayanan Tenaga

Administrasi Terhadap Efektivitas Kerja Guru SMA Negeri Di Kabupaten Indramayu. Edum Journal, 3(1)

\begin{abstract}
ABSTRAK
Di sekolah masih banyak ditemukan efektivitas kerja guru yang belum sesuai dengan harapan tujuan pendidikan nasional, seperti rerata hasil Ujian Nasional yang masih rendah, serta prosentasi outcome juga masih rendah. hal ini disebabkan oleh berbagai faktor, seperti lemahnya ; keterampilan manajerial kepala sekolah, pelayanan tenaga administrasi, dan sarana parasarana lainnya. Maka perlu diadakan penelitian pengaruh keterampilan manajerial kepala sekolah dan pelayanan tenaga administrasi terhadap efektivitas kerja guru. Adapun tujuan dari penelitian ini adalah untuk mengetahui pengaruh positif Keterampilan manajerial kepala sekolah $\left(\mathrm{X}_{1}\right)$, dan Pelayanan tenaga administrasi $\left(\mathrm{X}_{2}\right)$ terhadap Efektivitas kerja guru $(\mathrm{Y})$. Penelitian ini merupakan penelitian survey melalui pendekatan kuantitatif dengan populasi berjumlah 961 orang guru SMAN di Kabupaten Indramayu. Pada penelitian ini, peneliti menggunakan angket untuk mengambil data. Pengolahan datanya menggunakan aplikasi program SPSS. Hasil dari penelitian ini diperoleh informasi ; (1) Terdapat pengaruh positif dan signifikan keterampilan manajerial kepala sekolah $\left(\mathrm{X}_{1}\right)$ terhadap efektivitas kerja guru (Y), dengan besaran pengaruhnya 33\%. (2) Terdapat pengaruh positif dan signifikan pelayanan tenaga administrasi $\left(\mathrm{X}_{2}\right)$ terhadap efektivitas kerja guru $(\mathrm{Y})$, dengan besaran pengaruhnya $22 \%$.
\end{abstract}

Kata Kunci : Keterampilan Manajerial Kepala Sekolah, Pelayanan Tenaga Administrasi, Efektivitas Kerja Guru

ABSTRACT

In schools there are still many teacher effectiveness that is not in line with the expectations of national education goals, such as the average National Exam results which are still low, and the percentage of outcomes that are still low. this is caused by various factors, such as weakness; the principal's managerial skills, administrative services, and other infrastructure. Then it is necessary to conduct research on the influence of principals' managerial skills and service of administrative staff on the effectiveness of teacher work. The purpose of this study was to determine the positive influence of the principal's managerial skills (X1), and administrative personnel services (X2) on the effectiveness of teacher work (Y). This research is a survey research through a quantitative approach with a population of 961 high school teachers in Indramayu Regency. In this research, researches use qestionnaire to retrieve data. Processing data using the SPSS program application. The results of this study obtained information; (1) There is a positive and significant influence on the principal's managerial skills (X1) on the effectiveness of teacher work (Y), with a magnitude of influence of $33 \%$. (2) There is a positive and significant effect of administrative staff services (X2) on the effectiveness of teacher work (Y), with a magnitude of influence of $22 \%$.

Keywords : Principal's Managerial Skills, Administrative Staff Services, Teacher Work Effectiveness 


\section{A. Pendahuluan}

Guru merupakan salah satu komponen yang sangat menentukan untuk terselenggaranya proses pendidikan. Karena guru merupakan pelaku utama sebagai fasilitator penyelenggara proses belajar siswa. Oleh karena itu kehadiran dan profesionalismenya sangat berpengaruh dalam mewujudkan program pendidikan nasional. Guru harus memiliki kualitas yang cukup memadai, karena guru merupakan salah satu komponen mikro sistem pendidikan yang sangat strategis dan banyak mengambil peran dalam proses pendidikan di sekolah. Menurut undang-undang nomor 20 tahun 2003 tentang Sistem Pendidikan Nasional, pasal 39 dinyatakan bahwa ;

1. Tenaga kependidikan bertugas melaksanakan administrasi, pengelolaan, pengembangan, pengawasan, dan pelayanan teknis untuk menunjang proses pendidikan pada satuan pendidikan.

2. Pendidik merupakan tenaga professional yang bertugas merencanakan dan melaksanakan proses pembelajaran, menilai hasil pembelajaran, melakukan pembimbingan dan pelatihan, serta melakukan penelitian dan pengabdian kepada masyarakat, terutama bagi pendidik pada perguruan tinggi

Selanjutnya dalam Undang-undang nomor 14 tahun 2005 tentang Guru dan Dosen, pasal 1 ayat (1) disebutkan bahwa :

Guru adalah pendidik professional dengan tugas utama mendidik, mengajar, membimbing, mengarahkan, melatih, menilai, dan mengevaluasi peserta didik pada pendidikan usia dini jalur pendidikan formal, pendidikan dasar, dan penddidikan menengah.

Pelaksanaan proses belajar mengajar di kelas merupakan tugas pokok guru yang harus dilaksanakan secara efektif. Guru melakukan proses belajar secara efektif akan turut mempengaruhi kualitas belajarmengajar dan hasil belajar siswa. Hal ini dapat dimaklumi karena efektivitas itu berhubungan dengan pencapaian semua tujuan yang telah ditetapkan semula.

Mulyasa (2000:30) mendefinisikan bahwa, "Efektivitas adalah adanya ketepatan atau kesesuaian antara orang yang melaksanakan tugas dengan sasaran yang dituju". Efektivitas adalah bagaimana suatu organisasi berhasil mendapatkan dan memanfaatkan sumber daya dalam usaha mewujudkan tujuan organisasi.

Dengan demikian, efektivitas kerja guru ialah tingkat ketepatan guru dalam mengelola proses pembelajaran sehingga tercapai tujuan pembelajaran secara baik dan dengan menggunakan segala sumber daya dan dana secara tepat.

Adapun indikator kerja dapat mengacu pada pendapat Sudjana dkk, (2004:107) tentang kompetensi kerja guru yaitu : (1) mengusai bahan yang akan diajarkan, (2) mengelola program belajar mengajar, (3) mengelola kelas, (4) menggunakan media/sumber pembelajaran, (5) mengusai landasanlandasan kependidikan, (6) mengelola interaksi belajar mengajar, (7) menilai prestasi siswa, dan (8) mengenal fungsi dan program bimbingan dan penyuluhan.

Kabupaten Indramayu merupakan salah satu kabupaten yang mulai berkembang dengan pesat di Provinsi Jawa Barat dari sisi infrastruktur, namun dari aspek pendidikan kabupaten Indramayu ternyata belum sepenuhnya berkembang dengan pesat. Hal tersebut dapat terlihat dari peringkat hasil Ujian Nasional (UN) tahun 2015 - 2017 ditingkat provinsi Jawa Barat, bahwa hasil rerata UN SMA Negeri di kabupaten Indramayu masih belum menunjukan hasil yang signifikan berdasarkan data dari sekolah yang berda di Kabupaten 
Indramayu, dapat disimpulkan sebagai berikut :

1) hanya terdapat satu SMA Negeri yang memiliki rerata hasil UN yang cukup baik, serta memiliki peringkat yang signifikan di tingkat provinsi jawa barat, yaitu SMAN 1 Sindang.

2) masih terdapat 19 SMA Negeri yang belum mampu bersaing di tingkat provinsi Jawa Barat ditinjau dari sisi kognitif.

Hal ini menunjukan bahwa, secara kognitif Alumni SMA Negeri di kabupaten Indramayu secara umum masih tergolong rendah, itu berarti menggambarkan Efektifitas kerja guru SMA Negeri di Indramayu masih belum sesuai dengan harapan masyarakat pada umumnya, demikian juga dengan faktor outcome alumni yang masuk Perguruan Tinggi masih tergolong rendah. Ditambah lagi secara afektif dan psikomotor masih ada para alumni SMA yang terlibat kenakalan remaja, sehingga menambah deret beban efektivitas kerja Guru SMA pada umunya.

Kepala Disdik provinsi Jawa Barat, Dr. Ir. H. Ahmad Hadadi, M.Si, mengatakan :

"Kinerja guru yang efektif dan efisien akan menghasilkan sumber daya manusia (peserta didik) yang tangguh, yaitu lulusan yang memiliki daya saing, berdaya guna dan berhasil guna" (Sumber ; Rakor konsolidasi internal disdik jabar, tgl.24/03/2017)

Oleh karena itu kerja guru sangat penting untuk diperhatikan ; dikaji dan dievaluasi, karena guru memiliki amanat "mengemban tugas profesional" yang artinya tugas-tugas yang hanya dapat dikerjakan dengan kompetensi khusus yang diperoleh melalui program pendidikan. Guru memiliki tanggungjawab yang secara garis besar dapat dikelompokkan yaitu: (1). Guru sebagai pengajar, (2). Guru sebagai pembimbing dan (3). Guru sebagai administrator kelas. (Danim; 2002).

Berdasarkan pokok-pokok persoalan tersebut diatas, maka penulis tertarik untuk melakukan penelitian mengenai permasalahan efektivitas kerja guru SMA Negeri di Kabupaten Indramayu dengan rumusan masalahnya yaitu; Seberapa besar pengaruh keterampilan manajerial kepala sekolah dan pelayanan tenaga administrasi terhadap efektivitas kerja guru SMA Negeri di Kabupaten Indramayu?

\section{B. Maksud dan Tujuan}

Maksud dari penerlitian ini adalah untuk memperoleh informasi dengan cara mengungkapkan dan mendeskripsikan keterampilan manajerial kepala sekolah, pelayanan tenaga administrasi, dan efektivitas kerja guru SMA Negeri di Kabupaten Indramayu.

Sedangkan tujuan penelitian ini adalah :

Mendeskripsikan dan menganalisis besaran pengaruh keterampilan manajerial kepala sekolah, pelayanan tenaga administrasi, pelayanan tenaga administrasi, terhadap efekvitas kerja guru SMA Negeri di Kabupaten Indramayu

\section{Landasan Teori}

Pendidikan merupakan hal yang sangat penting dalam menentukan masa depan suatu bangsa. Kualitas pendidikan suatu bangsa akan banyak dipengaruhi oleh beberapa faktor seperti : Kepala sekolah, tenaga administrasi sekolah, guru, sarana dan prasarana lainnya yang mendukung proses pembelajaran.

\section{Efektivitas Kerja Guru}

Konsep efektivitas kerja sesungguhnya merupakan suatu konsep yang luas, mancakup berbagai factor baik didalam maupun diluar organisasi. Konsep 
efektivitas kerja ini oleh para ahli belum ada keragaman pandangan, dan hal tersebut dikarenakan sudut pandang yang dilakukan dengan pendekatan disiplin ilmu yang berbeda, sehingga melahirkan konsep yang berbeda pula dalam pengukurannya. Namun demikian, banyak juga para ahli dan peneliti yang telah mengemukakan apa dan bagaimana mengukur efektivitas kerja itu. Efektivitas kerja berarti penyelesaian pekerjaan tepat pada waktunya seperti yang telah ditetapkan sebelumnya (Siagian, 1986:152). Efektivitas kerja guru adalah para guru menghasilkan berbagai produk seperti rencana pembelajaran, kurikulum baru, pembelajaran, pemberian nasehat, konseling, dan rapat orangtua (Wayne K. Hoy dan Cecil G. Miskel, 2014:476). Menurut Rochmad, untuk menentukan kriteria efektif dalam setiap penelitian berbeda-beda, hal ini tergantung pada tiap tiap penelitian yang dilakukan (Ismunandar \& Nurafifah, 2018).

Terdapat tiga pendekatan yang diperlukan dalam mengukur efektivitas individu (Martani dan Lubis, 1987:55) yiatu : (1) Pendekatan sumber (resource approach) yakni mengukur efektivitas input. Pendekatan mengutamakan adanya keberhasilan organisasi untuk memperoleh sumber daya, baik fisik maupun non fisik yang sesuai dengan kebutuhan organisasi, (2) Pendekatan proses (proces approach) adalah untuk melihat sejauh mana efektivitas pelaksanaan program dari semua kegiatan proses internal atau mekanisme organisasi, dan (3) Pendekatan sasaran (goal approach) dimana pusat perhatian pada output, mengukur keberhasilan organisasi untuk mencapai hasil (output) yang sesuai rencana. Hasibuan (2001:31) mengemukakan bahwa terdapat beberapa hal yang perlu diperhatikan dalam pengukuran efektivitas sebuah organisasi diantaranya perencanaan, pengorganisasian, pengarahan, pengendalian, kedisiplinan dan pengembangan. Menurut Steers (1980:192) meliputi unsur kemempuan menyesuaikan diri / prestasi kerja dan kepuasan kerja: (1)Kemampuan menyesuaikan diri, (2)Kemampuan manusia terbatas daalam segala hal, sehingga dengan keterbatasannya itu menyebabkan manusia tidak dapat mencapai pemenuhan kebutuhannya tanpa melalui kerjasama dengan orang lain. Hal ini sesuai dengan pendapat Steers yang menyatakan bahwa kunci keberhasilan organisasi adalah kerjasama dalam pencapaian tujuan. Setiap orang yang masuk dalam organisasi dituntut untuk dapat menyesuaikan diri dengan orang yang bekerja didalamnya maupun dengan pekerjaan dlam organisasi tersebut. Jika kemampuan menyesuaikan diri tersebut dapat berjalan maka tujuan organisasi dapat tercapai. (3) Prestasi kerja, prestasi kerja adalah suatu hasil kerja yang dicapai seseorang dalam melaksanakan tugas-tugas yang dibebankan kepadanya yang didasarkan atas kecakapan, pengalaman, kesungguhan dan waktu (Hasibuan, 2001:94). (4) Kepuasan kerja, tingkat kesenangan yang dirasakan seseorang atas peranan atau pekerjaanya dalam organisasi. Tingkat rasa puas individu bahwa mereka mendapat imbalan yang setimpal, dari bermacam-macam aspek situasi pekerjaan dan organisasi tempat mereka berada. Dari pendapat tersebut dapat disimpulkan bahwa dengan kecakapan, pengalaman, kesungguhan waktu yang dimiliki pegawai maka tugas yang diberikan dapat dilaksanakan sesuai dengan tanggungjawab yang dibebankan kepadanya.

Menurut Mulyasa (2002:84) menungkapkan bahwa efektivitas kerja adalah bagaimana organisasi melaksanakan seluruh tugas pokoknya dan mencapai 
sasarannya, dapat dilihat berdasarkan pendekatan proses dengan uraian sebagai berikut : (1) input, yang meliputi karakteristik guru, fasilitas, perlengkapan dan materi pendidikan serta kapsitas manajemen, (2) proses, yang meliputi perilaku administrativ, alokasi waktu guru, dan alokasi waktu peserta didik, (3) output, yang meliputi jumlah kelulusan, dan prestasi belajar siswa di sekolah, (4) outcome, meliputi jumlah lulusan ke tingkat pendidikan berikutnya, prestasi belajar siswa di sekolah yang lebih tinggi. Maka yang menjadi dimensi untuk alat ukur efektivitas kerja guru dalam penelitian ini adalah : input (karakteristik guru), proses (alokasi waktu guru dalam aktivitas pembelajaran), output (target prestasi belajar siswa), outcome (target kelulusan dengan melihat nilai-nilai yang diperoleh peserta didik yang telah dicapainya).

\section{Keterampilan Manajerial Kepala Sekolah}

Menurut Robbins (1996:6-7), tiga keterampilan manajemen yang mutlak diperlukan kepala sekolah adalah ; konseptual, personal, dan teknikal.

\section{a. Keterampilan Konseptual}

Keterampilan konseptual adalah kemampuan mental untuk menganalisis dan mendiagnosis situasi rumit. Gagasan atau ide serta konsep tersebut dijabarkan menjadi suatu rencana kegiatan. Proses penajabaran ide menjadi suatu rencana kerja konkret itu sebagai proses perencanaan. Oleh karena itu, keterampilan konseptual menciptakan kemampuan untuk membuat rencana kerja. Keterampilan konseptual tidak sekedar merencanakan tetapi juga menganalisis, menafsirkan, dan memecahkan masalah selama pelaksanaan program, agar program itu berjalan dengan baik.

b. Keterampilan Personal
Keterampilan personal adalah kemampuan untuk berkomunikasi dengan individu lain, membangun kerjasama tim, motivasi, memehami orang lain, dan mendorong orang lain agar dapat bekerja sama dalam organisasi. Dalam bidang pendidikan keterampilan personal adalah kemampuan kepala sekolah untuk menciptakan sistim komunikasi dua arah yang terbuka dengan personil sekolah dan anggota masyarakat lainnya untuk menciptakan suasana kepercayaan terhadap sekolah dan menigkatkan efektivitas kerja guru.

\section{c. Keterampilan Teknikal}

Keterampilan teknikal ini sangat dibutuhkan oleh seorang kepala sekolah atau manajer. Sedangkan yang dimaksud dengan keterampilan teknikal ini adalah kemampuan untuk mempergunakan alat-alat dan teknik suatu bidang tertentu.

Oleh karena kepala sekolah berasal dari guru/guru pembimbing maka keterampilan teknik operasional mengajar/pelaksanaan pelayanan BK yang sudah dilakukannya bertahun-tahun. Maka dengan bekal pengalaman itu kepala sekolah secara teknis sudah memiliki keterampilan teknikal yang mumpuni.

\section{Pelayanan Tenaga Administrasi}

Berdasarkan Permendiknas No. 24 tahun 2008 tentang Standar Tenaga Administrasi Sekolah/Madrasah, mereka tenaga administrasi sekolah meliputi:

a. Kepala Tenaga Administrasi Sekolah

b. Pelaksana Urusan Administrasi Sekolah meliputi ; pelaksana urusan administrasi kepegawaian, pelaksana urusan administrasi keuangan, pelaksana urusan administrasi sarana prasarana, pelaksana urusan administrasi humas, pelaksana urusan administrasi persuratan dan kearsipan, pelaksana urusan administrasi 
kesiswaan, dan pelaksana urusan administrasi kurikulum

c. Petugas Layanan Khusus, meliputi ; penjaga sekolah, tukang kebun, pengemudi, dan pesuruh.

Menurut Nansen School $(2001 ; 17)$ Fungsi staff tata usaha adalah menangani urusan administrasi yang dibagi menjadi 4 bagian

a. Asisten Sekolah (School assistant)

b. Asisten Jurutulis/Administrasi (Clerical assistant)

c. Asisten Keuangan (Finance assistant)

d. Asisten Umum (General assistant)

\section{Kerangka Pikir Penelitian}

Berdasarkan dukungan landasan teoritik yang diperoleh dari eksplorasi teori yang dijadikan rujukan konsepsional variabel penelitian, maka dapat disusun kerangka pemikiran penelitian, seperti gambar 1 berikut ini;

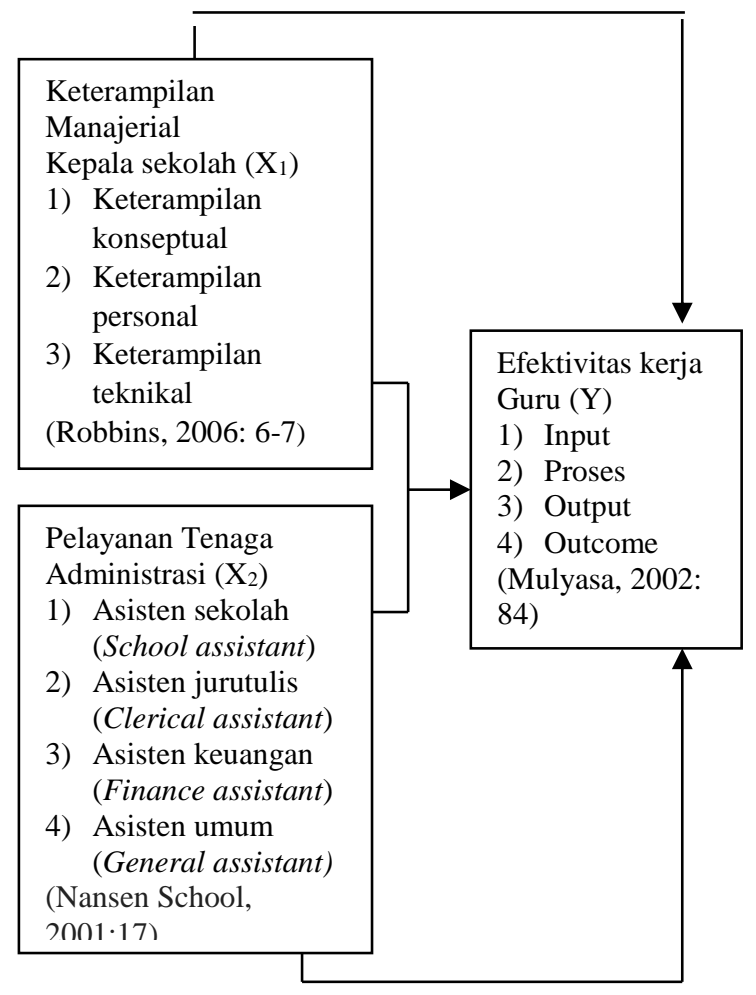

Gambar 1. Kerangka Pikir Penelitian

\section{Hipotesa Penelitian}

Hipotesa dari penelitian ini adalah sebagai berikut ;

a. Terdapat pengaruh positif dan signifikan Keterampilan manajerial kepala sekolah terhadap efektivitas kerja guru SMA Negeri di Kabupaten Indramayu

b. Terdapat pengaruh positif dan signifikan Pelayanan tenaga administrasi terhadap efektivitas kerja guru SMA Negeri di Kabupaten Indramayu

c. Terdapat pengaruh positif dan signifikan Keterampilan manajerial kepala sekolah dan Pelayanan tenaga administrasi secara bersama-sama terhadap efektivitas kerja guru SMA Negeri di Kabupaten Indramayu.

\section{Metode Penelitian}

Pada penelitian ini, peneliti memberikan angket kepada beberaapa guru di kabupaten Indramayu. Penelitian ini dilakukan untuk menganalisis hubungan variabel keterampilan manajerial kepala sekolah $\left(\mathrm{X}_{1}\right)$, dan pelayanan tenaga administrasi $\left(\mathrm{X}_{2}\right)$ dengan efektivitas kerja guru SMA Negeri di Kabupaten Indramayu. Penelitian ini menggunakan penelitian korelasi.

Menurut Riyanto (2010:34), "Penelitian korelasi adalah penelitian akan melihat hubungan antara variabel atau beberapa variabel dengan variabel lain. Masih menurut Riyanto (2010;34), "Ciri-ciri dari penelitan korelasi adalah ; 1) menghubungkan dua variabel atau lebih, 2) besarnya hubungan didasarkan pada koefisien korelasi, 3) dalam penelitan melihat hubungan tidak dilakukan manipulasi, 4) datanya bersifat kuantitatif.

Pendekatan penelitian yang digunakan adalah pendekatan kuantitatif. Sehingga bisa dikatakan bahwa penelitian ini adalah penelitian kuantitatif. Menurut Arifin 
(2018:25), "Penelitian kuantitatif dilaksanakan untuk menjelaskan, menguji hubungan antar variabel, menemukan kausalitas dari variabel, menguji teori dan mencari generalisasai yang mempunyai nilai prediktif terhadap suatu fenomena".

Populasi pada penelitian ini adalah semua guru SMA Negeri di Kabupaten Indramayu, yaitu berjumlah 961 orang. Pengambilan sampel menggunakan Arikunto (2008:120), "Untuk sekedar ancer-ancer maka apabila subjeknya kurang dari 100 maka dapat diambil keseluruhan, dengan demikian sampelnya totalitas. Selanjutnya jika subjeknya lebih dari 100 dapat diambil antara $10 \%-15 \%$, atau $20 \%-25 \%$ atau lebih, tergantung dari kemampuan peneliti". Sehingga rumus sampel yang dapat digunakan adalah :

$$
\mathrm{n}=15 \% \times \mathrm{N}
$$

dimana $: \mathrm{n}=$ jumlah sampel, dan $\mathrm{N}=$ jumlah populasi.

Dari rumus tersebut sampel yang diambil adalah 145 orang dengan teknik acak mewakili masing-masing sekolah.

\section{E. Hasil Penelitian dan Pembahasan}

\section{Gambaran Umum Obyek Penelitian}

Di kabupaten Indramayu terdapat 23

SMA Negeri yaitu: SMAN Anjatan, SMAN Bongas, SMAN Cantigi, SMAN Gabuswetan, SMAN Gatar, SMAN Haurgeulis, SMAN 1 Indramayu, SMAN 2 Indramayu, SMAN Jatibarang, SMAN Juntinyuat, SMAN Kandanghaur, SMAN Kedokanbunder, SMAN Krangkeng, SMAN Kroya, SMAN Lelea, SMAN Lohbener, SMAN Losarang, SMAN Sindang, SMAN Sliyeg, SMAN Sukagumiwang, SMAN Sukra, SMAN Terisi, dan SMAN Tukdana.

Jumlah guru di SMA Negeri Kabupaten Indramayu pada bulan Mei 2018 berjumlah 96ilorang dengan sampel yang diambil 145 orang.

\section{Karakteristik Responden}

Berdasarkan jenis kelamin, responden yang berjumlah 145 orang terdiri dari atas ; 44 orang dengan jenis kelamin laki-laki (30\%) dan 101 orang responden berjenis kelamin perempuan (70\%). Jadi sebagian besar penelitian ini adalah berjenis kelamin perempuan, yaitu sebesar $70 \%$.

Berdasarkan usia, terdiri atas ; 16 orang responden berusia antara $20-30$ tahun (11\%), 28 orang responden berusia antara 31-35 tahun (19\%), 57 orang responden berusia antara 36-40 tahun (39\%), 36 orang responden berusia antara 41-45 tahun (25\%), dan 8 orang responden berusia diatas 45 tahun $(6 \%)$.

Berdasarkan masa kerja, terdiri atas ; 38 orang responden dengan masa kerja 1-10 tahun $(26 \%), 57$ orang responden dengan masa kerja 11-20 tahun (39\%), dan 50 orang responden dengan masa kerja diatas 20 tahun $(35 \%)$.

Berdasarkan pendidikan, terdiri atas ; 134 orang responden berpendidikan S1 (89\%), dan 16 orang responden berpendidikan S2 (11\%). Jadi sebagian besar responden penelitian ini berpendidikan S1 yaitu sebanayak 134 orang atau $89 \%$ dari seluruh responden.

\section{Deskripsi Hasil Penelitian}

$\begin{array}{lcc}\text { a. Deskripsi } & \text { Tanggapan } & \text { Responden } \\ \text { terhadap } & \text { Keterampilan } & \text { Manajerial }\end{array}$ Kepala Sekolah

Berdasarkan hasil penelitian variabel keterampilan manajerial kepala sekolah $\left(\mathrm{X}_{1}\right)$ SMA Negeri di Kabupaten Indramayu yang dikur menggunakan 3 dimensi dan dioperasionalisasikan menggunakan 33 item pernyataan yang disertai dengan 5 pilihan jawaban yang diberi bobot 1 sampai 5, diperoleh skor rata-rata (mean) 115,58 dari skor ideal 165. Sehigga Angka Prosentasi 
(AP) tangapan responden terhadap keterampilan manajerial kepala sekolah sebesar $(115,58: 165) \times 100 \%=70,05 \%$. Jadi tanggapan responden terhadap manajerial kepala sekolah adalah baik.
b. Deskripsi Tanggapan Responden terhadap Pelayanan Tenaga Administrasi

Berdasarkan hasil penelitian variabel Pelayanan Tenaga Administrasi $\left(\mathrm{X}_{2}\right)$ SMA Negeri di Kabupaten Indramayu yang dikur menggunakan 4 dimensi dan dioperasionalisasikan menggunakan 36 item pernyataan yang disertai dengan 5 pilihan jawaban yang diberi bobot 1 sampai 5, diperoleh skor rata-rata (men) 118,57 dari skor ideal 180. Sehigga Angka Prosentasi (AP) tangapan responden terhadap keterampilan manajerial kepala sekolah sebesar $(118,57: 180)$ x $100 \%=65,87 \%$. Jadi tanggapan responden terhadap manajerial kepala sekolah adalah baik. c. Deskripsi Tanggapan Responden terhadap Efektivitas Kerja Guru

Berdasarkan hasil penelitian variabel Efektivitas Kerja Guru (Y) SMA Negeri di Kabupaten Indramayu yang dikur menggunakan 4 dimensi dan dioperasionalisasikan menggunakan 29 item pernyataan yang disertai dengan 5 pilihan jawaban yang diberi bobot 1 sampai 5, diperoleh skor rata-rata (men) 98,20 dari skor ideal 145. Sehigga Angka Prosentasi (AP) tangapan responden terhadap keterampilan manajerial kepala sekolah sebesar $(98,20: 145) \times 100 \%=67,72 \%$. Jadi tanggapan responden terhadap manajerial kepala sekolah adalah baik.

\section{Analisis Data Hasil Penelitian}

Angket yang sudah disebar diolah oleh peneliti, selanjutkan didapatkan data sebagai berikut.

Tabel 1. Hasil Angket Guru

\begin{tabular}{|c|c|c|c|c|c|}
\hline Variabel & No & Dimensi & $\begin{array}{c}\text { Jumlah } \\
\text { Soal }\end{array}$ & $\begin{array}{l}\text { Skor ideal tiap } \\
\text { variabel } \\
\left(S_{\text {it }}\right)\end{array}$ & $\begin{array}{c}\text { Skor rata-rata } \\
\text { (mean) tiap } \\
\text { variabel } \\
\left(\mathrm{X}_{\mathrm{i}}\right)\end{array}$ \\
\hline $\begin{array}{c}\text { Keterampilan } \\
\text { Manajerial }\end{array}$ & 1 & $\begin{array}{l}\text { Ketr. } \\
\text { Konseptual }\end{array}$ & 10 & 50 & 34,53 \\
\hline Kepsek $\left(\mathrm{X}_{1}\right)$ & $\begin{array}{l}2 \\
3\end{array}$ & $\begin{array}{l}\text { Ketr. Personal } \\
\text { Ketr. Teknikal } \\
\text { Jumlah }\end{array}$ & $\begin{array}{l}11 \\
12 \\
33\end{array}$ & $\begin{array}{c}55 \\
60 \\
165\end{array}$ & $\begin{array}{l}39,64 \\
41,42\end{array}$ \\
\hline $\begin{array}{c}\text { Pelayanan } \\
\text { Tenaga }\end{array}$ & 1 & $\begin{array}{l}\text { Asisten } \\
\text { Sekolah }\end{array}$ & 9 & 45 & 29,90 \\
\hline $\begin{array}{l}\text { Administrasi } \\
\qquad\left(\mathrm{X}_{2}\right)\end{array}$ & 2 & $\begin{array}{l}\text { Asisten } \\
\text { Jurutulis }\end{array}$ & 9 & 45 & 30,09 \\
\hline & 3 & $\begin{array}{l}\text { Asisten } \\
\text { Keuangan }\end{array}$ & 10 & 50 & 32,27 \\
\hline & 4 & $\begin{array}{l}\text { Asisten Umum } \\
\text { Jumlah }\end{array}$ & $\begin{array}{c}8 \\
36\end{array}$ & $\begin{array}{c}40 \\
180\end{array}$ & 26,32 \\
\hline Efektivitas & 1 & Input & 7 & 35 & 24,02 \\
\hline Kerja Guru (Y) & 2 & Proses & 8 & 40 & 27,06 \\
\hline
\end{tabular}




\begin{tabular}{llccc}
3 & Output & 8 & 40 & 27,92 \\
4 & Outcome & 6 & 30 & 19,20 \\
& Jumlah & 29 & 145 & \\
\hline
\end{tabular}

Setelah diketahui bahwa data berdistribusi normal dan berpola linear melalui uji statistik, selanjutnya menguji hipotesis. Hasil uji hipotesis seabagai berikut ;

$\begin{array}{llr}\text { a. Pengujian } & \text { Hipotesis } & \text { Pengaruh } \\ \text { Keterampilan } & \text { Manajerial } & \text { Kepala }\end{array}$

Tabel 2. Koefisien Persamaan Regresi

Variabel $\mathrm{X}_{1}$ terhadap $\mathrm{Y}$

\begin{tabular}{|c|c|c|c|c|c|c|}
\hline & \multirow[t]{2}{*}{ Model } & \multicolumn{2}{|c|}{$\begin{array}{l}\text { Unstandardized } \\
\text { Coefficients }\end{array}$} & \multirow{2}{*}{$\begin{array}{c}\text { Standardized } \\
\text { Coefficients } \\
\text { Beta }\end{array}$} & \multirow[t]{2}{*}{$\mathrm{t}$} & \multirow[t]{2}{*}{ Sig. } \\
\hline & & $\mathrm{B}$ & Std. Error & & & \\
\hline \multirow[t]{2}{*}{1} & (Constant) & 50,573 & 5,752 & & 8,792 & ,000 \\
\hline & $\begin{array}{l}\text { Keterampilan_Manaje } \\
\text { rial_Kepala_Sekolah }\end{array}$ & ,412 & ,049 &, 574 & 8,391 & ,000 \\
\hline
\end{tabular}

a. Dependent Variable: Efektivitas_Kerja_Guru

Sumber : Output perhitungan SPSS ver 23

Persamaan regresi dari hasil perhitungannya sebagai berikut ; $Y=a+b x 1 \rightarrow Y=50,573+$ $0,412 X \imath$. Konstanta sebesar 50,573 menyatakan bahwa jika tidak ada kenaikan nilai dari variabel keterampilan manajerial Kepala Sekolah (X1) maka nila efektivitas kerja guru adalah 50,573. Koefisien regresi sebesar 0,412 menyatakan bahwa setiap perubahan satu skor atau nilai keterampilan manajerial kepala sekolah akan memberikan kenaikan skor sebesar 0,412.

Selanjutnya pengujian signifikan dilaukan dengan membandingkan nilai probabilitas 0,05 dengan nilai probabilitas pada nilai Sig dalam tabel 1 diatas. Nilai Sig sebesar 0,000. Karena nilai Sig $(0,000)<$ nilai probabilitas $(0,05)$, maka dapat
Sekolah $\left(\mathrm{X}_{1}\right)$ terhadap Efektivitas Kerja Guru (Y)

Pengujian ini dilakukan dengan uji regresi linear dengan menggunakan program aplikasi SPSS. Hasilnya diperoleh seperti pada tabel 2 berikut ini ; 
dan diolah dengan program aplikasi SPSS.

Hasilnya terlihat pada tabel 3 berikut ;

Tabel 3. Koefisien Determinasi

\begin{tabular}{ccccc}
\multicolumn{5}{c}{ Variabel $\mathrm{X}_{1}$ terhadap Y } \\
\hline Model & $\mathrm{R}$ & R Square & $\begin{array}{c}\text { Adjusted } \\
\mathrm{R} \\
\text { Square }\end{array}$ & $\begin{array}{c}\text { Std. } \\
\text { Error of } \\
\text { the } \\
\text { Estimate }\end{array}$ \\
\hline 1 &, $574^{\mathrm{a}}$ &, 330 &, 325 & 11,259 \\
\hline
\end{tabular}

a. Predictors: (Constant),

Keterampilan_Manajerial_Kepala_Sekolah

b. Dependent Variable: Efektivitas_Kerja_Guru

Sumber : Output perhitungan SPSS ver 23

Berdassarkan tabel 3 tersebut diketahui bahwa nilai $\mathrm{R}$ Square sebesar 0,330 , artinya variabel Y (efektivitas kerja guru) dipengaruhi variabel $\mathrm{X}_{1}$ (keterampilan manajerial kepala skolah) sebesar 0,330 atau $33 \%$. Besar pengaruh managerial terhadap kinerja guru cukup tinggi yaitu sebesar $33 \%$. Namun demikian masih ada $63 \%$ hal-hal lain yang mempengaruhi kinerja guru b. Pengujian Hipotesis Pengaruh Pelayanan Tenaga Administrasi $\left(\mathrm{X}_{2}\right)$ terhadap Efektivitas Kerja Guru (Y)

Hasil uji regresi linear dengan menggunakan program aplikasi SPSS ver.23 diperoleh seperti pada tabel 4 di bawah ini ;

Tabel 4. Koefisien Persamaan Regresi Variabel $\mathrm{X}_{2}$ terhadap $\mathrm{Y}$

\begin{tabular}{|c|c|c|c|c|c|c|}
\hline & \multirow[t]{2}{*}{ Model } & \multicolumn{2}{|c|}{$\begin{array}{l}\text { Unstandardized } \\
\text { Coefficients }\end{array}$} & \multirow{2}{*}{$\begin{array}{c}\text { Standardized } \\
\text { Coefficients } \\
\text { Beta } \\
\end{array}$} & \multirow[t]{2}{*}{$\mathrm{t}$} & \multirow[t]{2}{*}{ Sig. } \\
\hline & & B & Std. Error & & & \\
\hline & (Constant) & 61,796 & 5,812 & & 10,632 & ,000 \\
\hline & Pelayanan_TAS & ,307 &, 048 & ,470 & 6,360 &, 000 \\
\hline
\end{tabular}

a. Dependent Variable: Efektivitas_Kerja_Guru

Sumber : Output perhitungan SPSS

Persamaan regresi dari hasil perhitungannya sebagai berikut ; $\mathrm{Y}=\mathrm{a}+\mathrm{bx}_{1} \rightarrow \mathrm{Y}=61,796+0,307 \mathrm{X} 1$. Konstanta sebesar 61,796 menyatakan bahwa jika tidak ada kenaikan nilai dari variabel pelayanan tenaga administrasi $\left(\mathrm{X}_{2}\right)$ maka nila efektivitas kerja guru adalah 61,796. Koefisien regresi sebesar 0,307 menyatakan bahwa setiap perubahan satu skor atau nilai pelayanan tenaga administrasi akan memberikan kenaikan skor sebesar 0,307 .

Selanjutnya pengujian signifikan dilakukan dengan membandingkan anatar nilai probabilitas 0,05 dengan nilai probabilitas pada nilai Sig dalam tabel 3 diatas. Nilai Sig sebesar 0,000. Karena nilai Sig $(0,000)<$ nilai probabilitas $(0,05)$, maka 
dapat disimpulkan bahwa terdapat pengaruh pelayanan tenaga administrasi $\left(\mathrm{X}_{2}\right)$ yang signifikan terhadap efektivitas kerja guru (Y).

Berdasarkan penjelasan diatas, maka pengujian hipotes kedua dalam penelitian ini dapat diketahui bahwa nilai Sig $(0,000)<$ nilai probabilitas $(0,05)$ sehingga hasilnya Ho ditolak dan $\mathrm{H}_{1}$ diterima, artinya terdapat pengaruh positif dan signifikan pelayanan tenaga administrasi $\left(\mathrm{X}_{2}\right)$ terhadap efektivitas kerja guru (Y) SMA Negeri di Kabupaten Indramayu.

Untuk mengetahui besaran pengaruh variabel $\mathrm{X}_{2}$ terhadap $\mathrm{Y}$ dengan cara menghitung besarnya koefisien deteminasi dan diolah dengan program aplikasi SPSS. Hasilnya terlihat pada tabel 6 berikut ;

Tabel 6. Koefisien Determinasi

Variabel $\mathrm{X}_{2}$ terhadap $\mathrm{Y}$

\begin{tabular}{ccccc}
\hline Model & $\mathrm{R}$ & R Square & $\begin{array}{c}\text { Adjusted R } \\
\text { Square }\end{array}$ & $\begin{array}{c}\text { Std. Error of the } \\
\text { Estimate }\end{array}$ \\
\hline 1 &, $470^{\mathrm{a}}$ &, 220 &, 215 & 12,144 \\
\hline
\end{tabular}

a. Predictors: (Constant), Pelayanan_TAS

b. Dependent Variable: Efektivitas_Kerja_Guru

Sumber : Output perhitungan SPSS ver 23

Dari tabel 6 tersebut diketahui bahwa nilai $\mathrm{R}$ Square sebesar 0,220, artinya variabel Y (efektivitas kerja guru) dipengaruhi variabel $\mathrm{X}_{2}$ (pelayanan tenaga administrasi) sebesar 0,220 atau $22 \%$.

c. Pengujian Hipotesis Pengaruh Keterampilan Manajerial Kepala

Tabel 7. Koefisien Persamaan Regresi

Variabel $\mathrm{Y}$ atas $\mathrm{X}_{1}$ dan $\mathrm{X}_{2}$

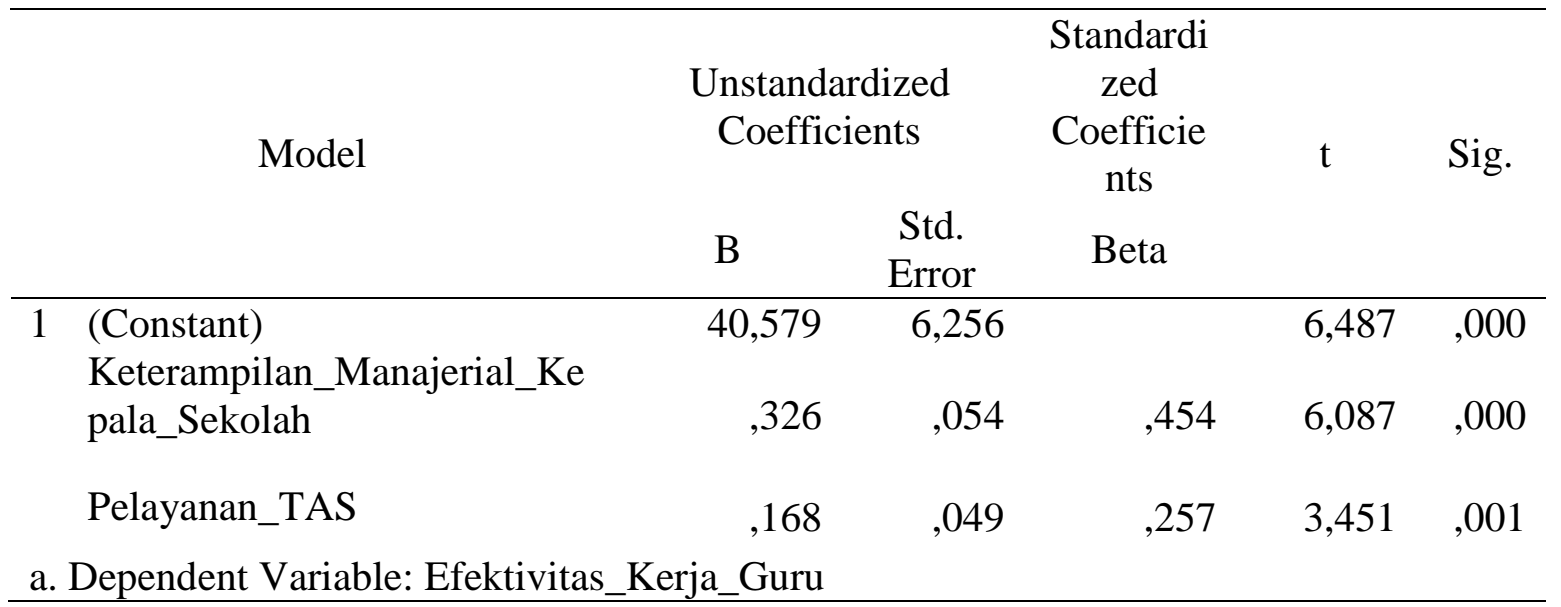


Dari tabel 7 menunjukan persamaan regresi dari hasil perhitungan olah data dengan aplikasi SPSS, yaitu :

$Y=a+b 1 X 1+b 2 X 2 \rightarrow Y=$ $40,579+0,326 X 1+0,168 X 2$.

Konstanta sebesar 40,579 menyatakan bahwa jika tidak ada kenaikan nilai dari variabel keterampilan manajerial kepala sekolah $\left(\mathrm{X}_{1}\right)$ dan pelayanan tenaga administrasi $\left(\mathrm{X}_{2}\right)$ maka nilai efektivitas kerja guru (Y) adalah 40,579.
Koefisien regresi sebesar 0,326 dan 0,168 menyatakan bahwa setiap perubahan satu skor atau nilai keterampilan manajerial kepala sekolah dan pelayanan tenaga administrasi akan memberikan kenaikan skor sebesar 0,326 dan 0,168 pada efektivitas kerja guru.

Selanjutnya persamaan tersebut diuji statistik, untuk mengetahui signifikan atau tidak, hasilnya seperti pada tabel 8 berikut ini ;

Tabel 8. Hasil Uji Signifikansi Regresi

Variabel $\mathrm{Y}$ atas $\mathrm{X}_{1}$ dan $\mathrm{X}_{2}$

\begin{tabular}{llrrrrr}
\hline \multirow{2}{*}{ Model } & \multicolumn{1}{c}{ Sum of } & Df & Mean Square & \multicolumn{1}{c}{ F } & \multirow{2}{*}{ Sig. } \\
\hline 1 & Regression & 10328,672 & 2 & 5164,336 & 43,8 & \multirow{2}{*}{, $000^{\mathrm{b}}$} \\
& & & & 44 & \\
& Residual & 16725,989 & 142 & 117,789 & & \\
$\quad$ Total & 27054,661 & 144 & & & \\
\hline
\end{tabular}

a. Dependent Variable: Efektivitas_Kerja_Guru

b. Predictors: (Constant), Pelayanan_TAS,

Keterampilan_Manajerial_Kepala_Sekolah

Sumber: Output perhitungan SPSS ver 23

Pengujian signifikansi untuk perhitungan regresi digunakan uji F. Pada tabel 7 menunjukan bahwa $F_{\text {hitung }}$ sebesar 43,844 dengan taraf signifikansi 0,000 kurang dari taraf nyata $0,05(\alpha=5 \%)$ dan jika dibandingkan dengan $F_{\text {tabel }}$ dengan kesalahan uji $5 \%$ derajat bebas 1 (dfi) sama dengan 2 dan derajat bebas 2 (df2) sama dengan 143 sebesar 2,34 , maka $F_{\text {hitung }}>F_{\text {tabel }}$ berarti persamaan $\mathrm{Y}=$ $40,579+0,326 \mathrm{X}_{1}+0,168 \mathrm{X}_{2} \quad$ signifikan. Artinya terdapat pengaruh yang signifikan antara keterampilan manajerial Kepala Sekolah $\left(\mathrm{X}_{1}\right)$ dan pelayanan tenaga administrasi $\left(\mathrm{X}_{2}\right)$ secara simultan (bersamasama) terhadap efektivitas kerja guru (Y) SMA Negeri di Kab. Indramayu .

Untuk mengetahui besaran pengaruh Keterampilan manajerial kepala sekolah $\left(\mathrm{X}_{1}\right)$ dan pelayanan tenaga administrasi $\left(\mathrm{X}_{2}\right)$ secara simultan terhadap efektivitas kerja guru (Y) SMA Negeri di Kabupaten Indramayu, dilakukan uji korelasi ganda dengan hasil seperti pada tabel 9 berikut ini.

Tabel 9. Perhitungan Uji Korelasi Ganda

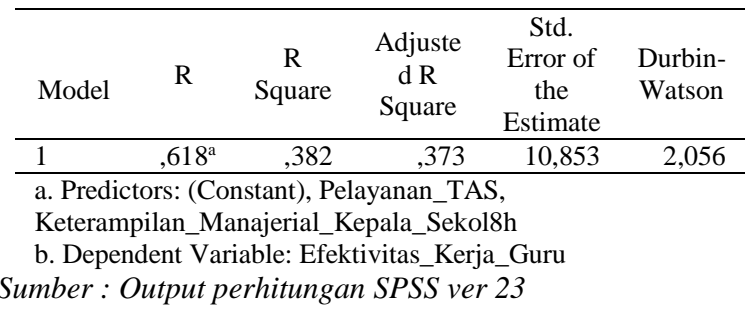

Berdasarkan hasil perhitungan program SPSS diatas, besarnya hubungan korelasi ganda antara varibel keterampilan manajerial kepala sekolah $\left(\mathrm{X}_{1}\right)$ dan pelayanan tenaga administrasi $\left(\mathrm{X}_{2}\right)$ secara silmultan terhadap efektivitas kerja guru (Y) 
yang dihitung dengan $R$ Square adalah 0,382 . Hal ini menunjukan adanya pengaruh yang positif antata keterampilan manajerial kepala sekolah $\left(\mathrm{X}_{1}\right)$ dan pelayanan tenaga administrasi $\left(\mathrm{X}_{2}\right)$ secara silmultan terhadap efektivitas kerja guru (Y) sebesar 0,382 atau $38,2 \%$.

Berdasarkan penjelasan diatas, maka hasil dari pengujian hipotesis ketiga dalam penelitian ini Ho ditolak dan $\mathrm{H}_{1}$ diterima, artinya terdapat pengaruh positif dan signifikan keterampilan manajerial kepala sekolah dan pelayanan tenaga administrasi secara simultan terhadap efektivitas kerja guru SMA Negeri di Kabupaten Indramayu.

Untuk menyatakan besarnya pengaruh variabel ketermapilan manajerila kepala sekolah $\left(\mathrm{X}_{1}\right)$ dan pelayanan tenaga administrasi $\left(\mathrm{X}_{2}\right)$ secara silmultan terhadap efektivitas kerja guru (Y) dapat diketahui dari tabel diatas, yaitu pada $R$ Square sama dengan 0,382 atau $38,2 \%$. Hal ini memberikan arti bahwa ketermapilan manajerila kepala sekolah $\left(\mathrm{X}_{1}\right)$ dan pelayanan tenaga administrasi $\left(\mathrm{X}_{2}\right)$ secara silmultan terhadap efektivitas kerja guru (Y) sebesar $38,2 \%$.

d. Struktur Hubungan antara variabel $X_{1}$, $\mathrm{X}_{2}$, dan $\mathrm{Y}$

Dari hasil pengujian semua hipotesis penelitian diatas, dapat digambarkan struktur hubungan dan hasil pengujian antara variabel $\mathrm{X}_{1}, \mathrm{X}_{2}$, dan $\mathrm{Y}$ terlihat seperti pada Gambar 2 berikut ini ;

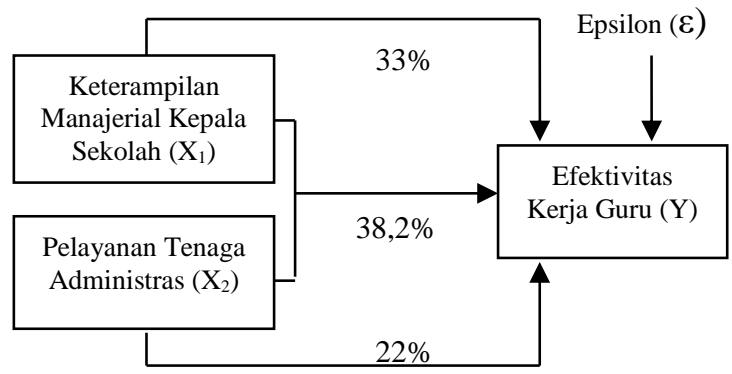

Gambar 2. Hubungan antara Variabel dan Hasil Pengujian Penelitian
Keterangan ;

$33 \%=$ Pengaruh variabel $\mathrm{X}_{1}$ terhadap $\mathrm{Y}\left(\mathrm{ryx}_{1}\right)$

$22 \%=$ Pengaruh variabel $\mathrm{X}_{2}$ terhadap $\mathrm{Y}\left(\mathrm{ryx}_{2}\right)$

$38,2 \%=$ Pengaruh variabel $X_{1}$ dan $X_{2}$ terhadap $\mathrm{Y}\left(\mathrm{ry}\left(\mathrm{x}_{1} \mathrm{x}_{2}\right)\right)$

$\varepsilon=$ Variabel lain yang tidak diteliti

\section{Pembahasan Hasil Penelitian}

Rumusan masalah yang pertama dalam penelitian ini adalah "Seberapa besar pengaruh keterampilan manajerial kepala sekolah terhadap efektivitas kerja guru SMA Negeri di Kabupaten Indramayu?". Dari hasil penelitian diperoleh informasi : (1) Keterampilan manajerial kepala sekolah meliputi dimensi ; keterampilan konseptual, keterampilan personal, dan keterampilan teknikal mendapat respon yang baik dari responden guru SMA Negeri Kabupaten Indramayu sebesar 70,05\%. (2) Terdapat pengaruh posistif dan signifikan keterampilan manajerial kepala sekolah terhadap efektivitas kerja guru SMA Negeri di Kabupaten Indramayu. (3) Besaran pengaruh keterampilan manajerial kepala sekolah terhadap efektivitas kerja guru SMA Negeri di Kabupaten Indramayu adalah $33 \%$.

Rumusan masalah yang kedua dalam penelitian ini adalah "Seberapa besar pengaruh pelayanan tenaga administrasi terhadap efektivitas kerja guru SMA Negeri di Kabupaten Indramayu?". Dari hasil penelitian diperoleh informasi : (1) Pelayanan tenaga administrasi meliputi dimensi ; asisten sekolah, asisten juru tulis, asisten keuangan dan asisten umum mendapat respon yang baik dari responden guru SMA Negeri Kabupaten Indramayu sebesar 65,87\%. (2) Terdapat pengaruh posistif dan signifikan Pelayanan tenaga administrasi terhadap efektivitas kerja guru SMA Negeri di Kabupaten Indramayu. (3) Besaran pengaruh Pelayanan tenaga administrasi terhadap efektivitas kerja guru 
SMA Negeri di Kabupaten Indramayu adalah $22 \%$.

Rumusan masalah yang ketiga dalam penelitian ini adalah "Seberapa besar pengaruh keterampilan manajerial kepala sekolah dan pelayanan tenaga administrasi secara simultan terhadap efektivitas kerja guru SMA Negeri di Kabupaten Indramayu?". Dari hasil penelitian diperoleh informasi : (1) Efektivitas kerja guru meliputi dimensi ; input, proses, output, dan outcome mendapat respon yang baik dari responden guru SMA Negeri Kabupaten Indramayu sebesar $67,72 \%$. (2) Terdapat pengaruh posistif dan signifikan keterampilan manajerial kepala sekolah dan Pelayanan tenaga administrasi terhadap efektivitas kerja guru SMA Negeri di Kabupaten Indramayu. (3) Besaran pengaruh keterampilan manajerial kepala sekolah dan pelayanan tenaga administrasi secara simultan terhadap efektivitas kerja guru SMA Negeri di Kabupaten Indramayu adalah $38,2 \%$.

\section{F. Kesimpulan dan Saran \\ 1. Kesimpulan}

Hasil pengujian hipotesis menunjukan bahwa ketiga hipotesis kerja $\left(\mathrm{H}_{1}\right)$ yang diajukan dalam penelitian ini semuanya diterima, dan menolak semua hipotesis nol $\left(\mathrm{H}_{\mathrm{o}}\right)$

Terdapat pengaruh positif dan signifikan keterampilan manajerial kepala sekolah terhadap efektivitas kerja guru. Besaran pengaruh keterampilan manajerial kepala sekolah terhadap efektivitas kerja guru adalah $33 \%$.

Terdapat pengaruh positif dan signifikan pelayanan tenaga administrasi terhadap efektivitas kerja guru. Besaran pengaruh pelayanan tenaga administrasi terhadap efektivitas kerja guru adalah $22 \%$
Terdapat pengaruh positif dan signifikan keterampilan manajerial kepala sekolah dan pelayanan tenaga administrasi terhadap efektivitas kerja guru. Besaran pengaruh keterampilan manajerial kepala sekolah dan pelayanan tenaga administrasi terhadap efektivitas kerja guru adalah $38,2 \%$.

\section{Saran}

Dari kesimpulan di atas, penulis menyampaikan beberapa saran sebagai berikut;

a. Bagi Kepala Dinas Pendidikan

Dengan hasil penelitan ini yang membuktikan bahwa terdapat pengaruh positif dan signifikan keterampilan manajerial kepala sekolah dan pelayanan tenaga administrasi terhadap efektivitas kerja guru, maka untuk meningkatkan efektivitas kerja guru, dinas pendidikan perlu memberikan pendidikan, pelatihan atau penguatan yang berkenaan dengan peningkatkan efektivitas kerja guru.

b. Bagi Kepala Sekolah

Dengan terbuktinya keterampilan manajerial kepala sekolah dan pelayanan tenaga administrasi pada efektivitas kerja guru, maka untuk meningkatkan efektivitas kerja guru di sekolah kepala sekolah wajib melakukan supervise akademik secara berkala maupun supervise klinis

c. Bagi Guru

Guru harus mampu meningkatkan kompetensinya, baik kompetensi sosial, kompetensi kepribadian, kompetensi pedagogik, maupun kompetensi profesionalnya sehingga efektivitas kerja guru semakin meningkat.

d. Bagi Peneliti Selanjutnya

Penelitian yang dilakukan oleh penulis, terbatas pada pengaruh keterampilan manajerial kepala sekolah dan pelayanan tenaga administrasi terhadap efektivitas kerja guru, masih terdapat variabel lain yang 
mempengaruhi efektivitas kerja guru, seperti budaya sekolah, lingkungan masyarakat, dan sebagainya. Untuk itu penulis menyarankan kepada peneliti selanjutnya agar meneliti variabel-variabel lainnya yang mempengaruhi efektivitas kerja guru

\section{G. Daftar Pustaka}

Arifin Rois dkk. (2018). Budaya dan Perilaku Organisasi. Malang: Empat dua

Arikunto, S. (2008). Metodologi Penelitian. Yogyakarta: Bina Aksara

Chaerunnisa C. (2016). Manajemen Pendidikan dalam Multi Perspektif. Jakarta: PT RajaGrafindo Persada.

Danim, Sudarwan. (2008). Kinerja Staf dan Organisasi. Bandung: CV Pustaka Setia.

Hasibuan. (2001). Manajemen Sumber Daya Manusia. Jakarta: Bumi Aksara

Ismunandar, D \& Nurafifah, L. (2018). Efektifitas Penggunaan Buku Ajar Berbantuan Geogebra untuk Mencapai Ketuntasan Hasil Belajar Matematis. Dialektika, 5(2), 70-85

Mulyasa E. (2005). Menjadi Kepala Sekolah Professional. Bandung: PT Remaja Rosdakarya (2002). Manajemen Berbasis Sekolah. Bandung: PT Remaja Rosdakarya

PP Nomor 19 tahun 2005 tentang Standar Nasional Pendidikan. Jakarta: BP Cipta Jaya

Robbin, Stephen P. (2006). Perilaku Organisasi (Alih bahasa: Benyamin Molan). Klaten: PT Indek, Kelompok Gramedia

Ruseffendi. (2005). Dasar-dasar Penelitian Pendidikan. Bandung: Tarsito

Siagian, Pondang P. (1986). Fungsi-fungsi Manajemen. Jakarta: PT Gunung Agung (1994). Teori Pengembangan Organisasi. Jakarta: Bumi Aksara

Steers, Richard M. (1980). Efektivitas Organisasi. Terjemahan Sofyan Cikmat. Jakarta: Erlangga

Sudjana, Nana. (2004). Penilaian Hasil Proses Belajar Mengajar. Bandung: Remaja Rosda Karya
Supardi. (2014). Kinerja Guru. Jakarta: PT Raja Grafindo Persada 